\title{
Achieving Sustainable Development in Small Communities via Combined Heat and Power Systems
}

\author{
Olaosebikan A. Olafadehan ${ }^{1}$, Lukumon Salami ${ }^{2}$, Babatunde K. Adeoye ${ }^{1}$, Toluwalase O. Ajayi ${ }^{1}$ \\ ${ }^{1}$ Department of Chemical Engineering, University of Lagos, Lagos, Nigeria \\ ${ }^{2}$ Department of Chemical and Polymer Engineering, Lagos State University, Lagos, Nigeria \\ Email: oolafadehan@unilag.edu.ng,olafadehan@yahoo.com
}

Received September 25, 2011; revised December 10, 2011; accepted December 22, 2011

\begin{abstract}
The design of a feasible Combined Heat and Power plant for a small community is presented. Of the many alternatives solid-waste disposal methods available, incineration of solid waste is recommended due to its potential energy recovery of the heat released during solid waste incineration and recovery of valuable by-products that can either be reused, recycled or marketed, among other advantages. Hence, an attempt is made to use the heat energy released during incineration of solid waste to produce steam in a boiler, which in turn powers a turbine for eventual generation of electricity. The two processes involved in the generation of electricity for in-plant use or for a small community via a steam turbine-generator combination and a gas compressor-gas turbine-generator are presented. The analysis of the amount of energy produced from the solid waste energy-conversion system using an incinerator-boiler-steam turbine-electric generator combination with a capacity of 4.5 tons/day is also presented. The net electric power for a small community was found to be $148.24 \mathrm{~kW}$ with an overall efficiency of about $21 \%$ having taken cognisance of the process power needs and unaccounted process heat losses. Moreover, exergy analysis of the proposed CHP plant was carried out whereby the respective energy and exergy efficiencies of $83.2 \%$ and $62.1 \%$ were obtained.
\end{abstract}

Keywords: Sustainable Development; Solid Waste; Incineration; Boiler; Turbine; Electric Generator; CHP; Efficiency; Exergy

\section{Introduction}

Today, the total population of developing countries, Nigeria inclusive, accounts for more than $70 \%$ of the world's population. Waste management in these countries is of grave concern from two points of view. Firstly, the process of urbanisation and population concentration that is inextricably linked to waste management issue is progressing at a pace that is much faster than was ever experienced by today's industrialised countries. Secondly, these countries have often difficulty in streamlining the institutional system, administrative bodies, management capabilities and human resources that are needed to take the lead in solving solid waste problems. It is thus very difficult for them to respond effectively to the newly emerging challenge of solid waste management [1].

Recognising that the world is finite and that the continued pollution of our environment will, if uncontrolled, be difficult to rectify in the future, the subject of solid waste management is both timely and important. The overall objective of solid waste management is to minimise the adverse environmental effects caused by the indiscriminate disposal of solid waste [2]. Serious effects of improper waste management include air pollution, contamination of drinking water supplies, spread of diseases, and bad aesthetics of the environment [3].

Man's current lifestyle is unsustainable; energy usage is on the increase with every technological advancement. There is, therefore, the need to enhance energy generation and one good source is biomass, regarded as waste. Moreover, sustainable development is one of the most significant issues facing society today. Population and consumption growth are believed to grow exponentially while resource production grows in a linear fashion. It is, therefore, believed that for new technologies to be sustainable, there is the need to save resources and avoid waste or better still use waste as raw materials.

Natural ecological systems are sustainable because they reject the concept of waste; the so-called waste from one component of the biogeochemical cycle is raw material for another component: this causes ecological systems to operate in a closed loop with minimal interaction from and to the environment.

About $70 \%$ of the components that comprise solid waste are organic hence the potential for the recovery of energy is high. The energy contained in the organic matter must be recovered to a form that can be used more 
easily. The recovery of heat by burning the organic material in solid waste is the option that is spoken of most frequently [2].

Every country in the world is dependent upon energy to maintain its standard of living. There are considerable variations between countries in the amount of energy used: at present about half the world's population uses $90 \%$ of the total available energy. The analysis of the manner in which energy is utilised is based on the first law of thermodynamics, and this suggests that the effective utilisation of energy is only just over $50 \%$. It is also possible to present energy analyses in terms of second law of thermodynamics and, with interesting conclusions, in relation to environmental impact.

Over the past hundred years, the world has been mainly dependent upon 1) the basic fossil fuels: coal, oil and natural gas; 2) electricity generated by hydro- or nuclear means; 3) wood and related low-grade fuels; and 4) solar energy. The extent to which each resource has been used has varied over the years. Wood was the major energy source some hundred years ago, then coal became dominant until the early 1960s when oil became the major world energy source. The factors that determined their roles have been availability, cost and the ability to match the energy source with particular applications.

The necessity to save energy in most countries in the world is a fairly recent phenomenon brought about in the main by very large increase in oil prices in 1973-1974 to date. The prospect of an oil famine and the world problem are of increasing concern to industrialised and developing nations. Their interest is substantially increased with realisation that countries like Europe and North America have relatively small indigenous oil resources in relation to their consumption, and that their sources of supply are in areas of the world where supply and political stability cannot be guaranteed.

Coal and nuclear energy play major roles in electricity generation, particularly if there is to be any expansion. Both pose inherent environmental problems, which will become increasingly severe with time. Moreover, the nuclear contribution faces potential difficulties because of the apprehension of most countries toward development of a nuclear plant.

Investigations into alternatives for heating and electricity generation are being carried out worldwide. Proposed alternative energy supplies suitable for electricity generation include solar, wind, wave, biomass and tidal power. The use of biomass, especially combustible mass regarded as waste, has been utilised in developed countries in Combined Heat and Power (CHP) plants to augment electricity generation. Figure 1 shows countries where CHP plants contribute to the total national generation. Hence, there is a growing need for information and expertise on CHP, which is potentially the most significant

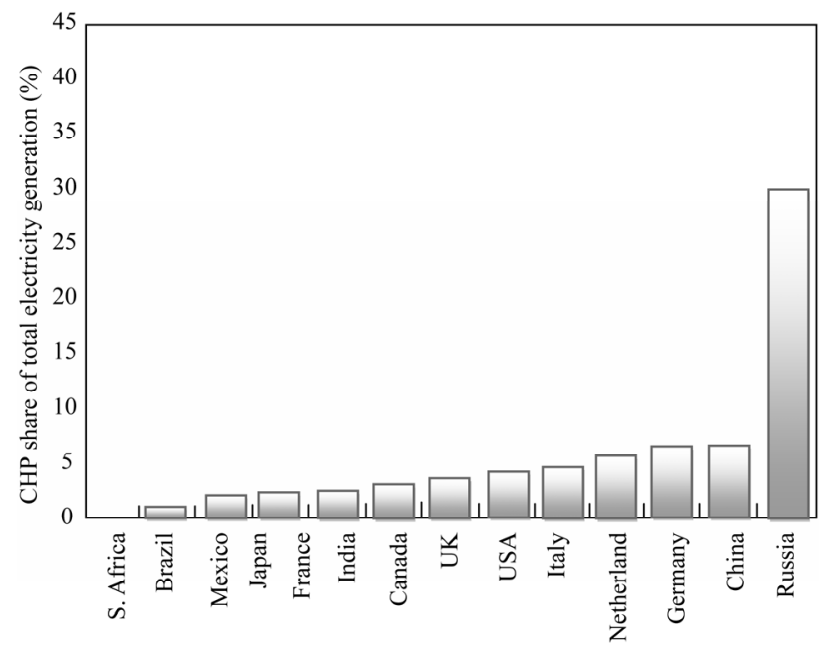

Source: IEA data and analysis; data merged from years 2001, 2005, 2006.

Figure 1. CHP share of total electricity generation in fourteen countries.

energy saving technology. The energy saving options available include the CHP system where the waste heat from solid waste incineration is recoverable and subsequently used to generate electricity, and where biomass is incinerated so as to recover the energy latent (or inherent) in the biomass. The advantages obtainable through the use of a well-designed CHP plant include the following:

1) The dual system for generating electric power and heat makes possible overall energy utilisation efficiencies in excess of $70 \%$, as contrasted with about $35 \%$ for the generation of electricity alone.

2) It results in correspondingly reduced emissions of pollution combustion products.

3) The delivery of fuel oil by truck to may locations is eliminated, with a savings in cost and traffic congestion.

4) It displaces the firing elsewhere of other, less efficient and dirtier plant.

5) It has a higher efficiency hence it results in energy cost savings.

6) Its maintenance and operating costs are reduced.

7) Reliability of services is improved.

8) Fire hazards associated with the storage, handling, and combustion of fuel are eliminated hence, insurance rate may be decreased.

Of the many alternatives solid-waste disposal methods available, which include hog feeding, open dumps, sanitary landfills, incineration, ocean dumping, composting, land-farming and deep-well injection, incineration is preferred due to its numerous advantages over other disposal methods:

1) It is an excellent disposal technology for all substances that have high heat-release potential e.g. liquid and solid hydrocarbons.

2) It offers detoxification of all combustible carcinogens, mutagens, teratogens, pathological wastes as well 
as substances that are biologically active, that may adversely affect other treatment processes.

3) It offers the opportunity to better manage potential air emissions.

4) It possesses potential energy recovery of the heat released and recovery of valuable by-products that can either be reused, recycled, or marketed.

While incineration of solid wastes offers many potential advantages, it also has its drawbacks which include:

1) Its initial capital investment is higher than that for many other treatment technologies.

2) The control of incineration operation requires highly trained operators.

3) Solid-waste incineration operation is highly complex owing to variance in the waste composition and the severe operating conditions required to achieve desirable thermal destruction efficiencies.

4) Incineration of some solid wastes (e.g. hazardous waste) can potentially impact human health and the environment; hence emissions of odours, particulates, and hazardous gaseous substances must be controlled so as to keep these undesirable air pollutants from being emitted into the atmosphere.

The concept that the abundant heat currently lost in the incineration of solid waste can be recovered and used for other purposes rather than being wasted to the atmosphere, is not yet fully explored in Nigeria. Hence, this work is intended to consider the incineration of solid waste with emphasis on energy recovery via CHP. Energy recovery via employing the heat generated during incineration of solid waste to produce steam or using the hot gases emitted during incineration with the aim of turning a turbine, which can be used to generate power for a small community is the aim and objective of this work. This work is, therefore, of great relevance to a small community for power generation.

This study only covers the design of a small on-site total energy system (integrated utility systems) for a community like housing complex, university or other institutions but does not cover the costing and profitability analysis of both processes shown in Figures 2 and 3, with the aim of determining which process is more economically viable.

\section{Theory}

The moisture content of solid wastes is expressed as the mass of moisture per unit mass of wet or dry material. The wet-mass moisture content, $M$, is given by:

$$
M=\left(\frac{a-b}{a}\right) \times 100
$$

where $a$ is the initial mass of solid-waste sample as delivered, and $b$ mass of sample after drying.

To obtain the dry mass, the solid waste material is dried

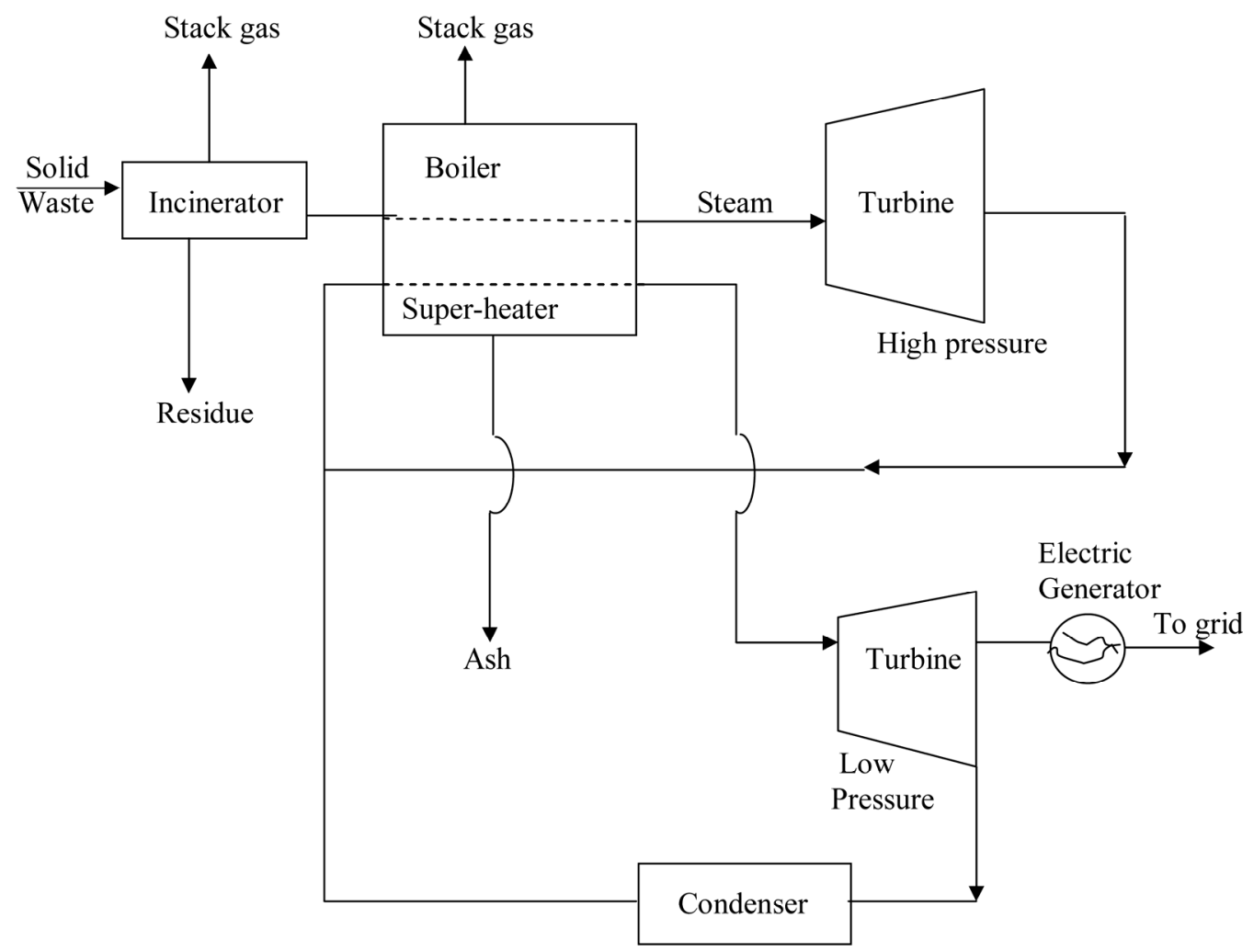

Figure 2. Energy-recovery systems with steam turbine-generator (Ralph, 2001). 


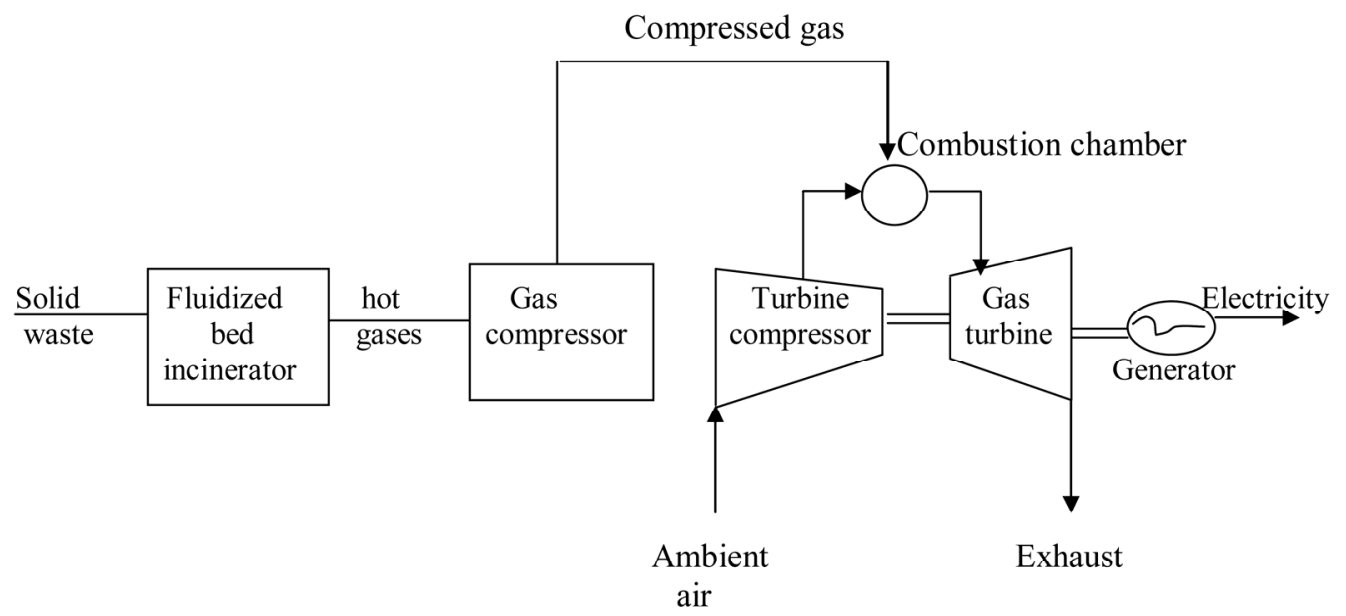

Figure 3. Energy-recovery systems with gas compressor-gas turbine-generator.

in an oven at $77^{\circ} \mathrm{C}$ for $24 \mathrm{~h}$ in order to dehydrate the material completely, and to limit the vaporisation of volatile materials.

The energy value, $E$, for solid waste on a dry basis is found using:

$$
E=E_{d}\left(\frac{100}{100-M}\right)
$$

The corresponding equation for the energy value, $E^{\prime}$, on an ash-free dry basis is given by:

$$
E^{\prime}=E_{d}\left(\frac{100}{100-A^{\prime}-M}\right)
$$

The heat released from the combustion of solid wastes is partly stored in the combustion products (gases and ash) and partly transferred by convection, conduction and radiation to the incinerator wall and to the incoming waste. The energy content of the waste can be estimated using the modified Dulong equation [4], given by:

$$
E=337 \mathrm{C}+1428\left(\mathrm{H}-\frac{\mathrm{O}}{8}\right)+95 \mathrm{~S}
$$

For a boiler, liquid water is assumed to enter the boiler below its boiling point (i.e. at $25^{\circ} \mathrm{C}$ ), and is heated in the liquid phase before vaporisation occurs. To utilise further the high temperature source of heat and to limit consideration, the steam leaving the boiler is superheated above the saturation temperature. The energy equation is represented by:

$$
\begin{aligned}
& \left(\begin{array}{l}
\text { Enthalpy } \\
\text { change }
\end{array}\right)+\left(\begin{array}{l}
\text { Kinetic } \\
\text { change }
\end{array}\right)+\left(\begin{array}{l}
\text { Potential } \\
\text { change }
\end{array}\right) \\
= & \left(\begin{array}{l}
\text { Heat energy } \\
\text { transfer }
\end{array}\right)-\left(\begin{array}{l}
\text { Work done } \\
\text { by system }
\end{array}\right)
\end{aligned}
$$

Based on unit mass of fluid passing through a control volume, we have:

$$
\Delta H+\frac{1}{2} U^{2}+g \Delta z=Q-W_{s}
$$

The primary purpose of steam boiler is to transfer heat to the water; energy effects accompanying changes in elevation and velocity are small. Also, there is no mechanical energy exchange to the surroundings so that the work term disappears. Hence, Equation (6) reduces to:

$$
Q=\Delta H
$$

The high temperature steam from the boiler goes to high pressure turbine, as shown in Figure 2, where part of its energy is converted to work. The process follows constant entropy line since it is reversible and adiabatic. The process in the turbine is assumed to be adiabatic and the overall changes in kinetic and potential energies are relatively small. Equation (6) therefore reduces to:

$$
W_{s}=-\Delta H
$$

Equation (8) indicates that the work obtained is entirely at the expense of the change in enthalpy of the expanding steam. Thus, $W_{S}$ can be evaluated directly from the initial and final states with data from the steam table. Equation (8) also applies to a gas compressor considered in this work assuming adiabatic condition and neglecting the changes in potential and kinetic energies.

The gas turbine in Figure 3 utilises high temperature gases from the combustion space to operate an expansion turbine. The higher the temperature of the combustion gases entering the turbine, the higher the efficiency, $W_{S} / Q$, of the unit (based on $1 \mathrm{~mol}$ of air). The compressor process is an adiabatic reversible (isentropic) step in which the pressure is increased from atmospheric pressure $p_{A}$ to $p_{b}$ (process $A B$ ). The actual combustion process is replaced by the constant-pressure addition of an amount of heat, $Q_{B C}$ (process $B C$ ). The turbine expansion produces work by an isentropic expansion to the pressure, $p_{D}$ (process $C D$ ). The hot gases from the turbine are ex- 
hausted to the electric generator while the exhaust air is to the atmosphere. The efficiency, $\eta$, of the gas turbine is given as:

$$
\eta=\frac{W_{S}}{Q_{B C}}=\frac{W_{C D}+W_{A B}}{Q_{B C}}
$$

The work done by the air in passing through the compressor is given by the application of the energy Equation (6) for a steady-state flow process. Neglecting the small potential and kinetic energies' contributions, Equation (6) reduces to:

$$
-W_{A B}=H_{B}-H_{A}
$$

If the specific heat is constant, the enthalpy change for an ideal gas is written as:

$$
-W_{A B}=H_{B}-H_{A}=C_{p}\left(T_{B}-T_{A}\right)
$$

Applying the energy equation to the combustion and turbine processes, we have:

$$
\begin{aligned}
-W_{C D} & =C_{p}\left(T_{D}-T_{C}\right) \\
Q_{B C} & =C_{p}\left(T_{C}-T_{B}\right)
\end{aligned}
$$

Using Equations (11) to (13) in Equation (9), we have:

$$
\eta=1-\frac{T_{D}-T_{A}}{T_{C}-T_{B}}
$$

Since pressure $A B$ and $C D$ are isentropic, the temperature and pressure are related as follows:

$$
\begin{aligned}
& \frac{T_{B}}{T_{A}}=\left(\frac{p_{B}}{p_{A}}\right)^{\frac{\gamma-1}{\gamma}} \\
& \frac{T_{D}}{T_{C}}=\left(\frac{p_{D}}{p_{C}}\right)^{\frac{\gamma-1}{\gamma}}
\end{aligned}
$$

Using Equations (15) and (16) to eliminate $T_{A}$ and $T_{D}$ from Equation (14), the efficiency, $\eta$, of the gas turbine in terms of the pressure ratio is then given by:

$$
\eta=1-\left(\frac{p_{A}}{p_{B}}\right)^{\frac{\gamma-1}{\gamma}}
$$

The efficiency of the centrifugal compressor and gas turbine is given as:

$$
\eta=\frac{\eta_{t} \eta_{c}\left(\frac{T_{C}}{T_{A}}\right)\left(1-\frac{1}{\alpha}\right)-(\alpha-1)}{\eta_{c}\left(\frac{T_{C}}{T_{A}}-1\right)-(\alpha-1)}
$$

where

$$
\alpha=\left(\frac{p_{B}}{p_{A}}\right)^{\frac{\gamma-1}{\gamma}}
$$

\section{Design of CHP Plant}

The major items of equipment to be designed in a Combined Heat and Power (CHP) plant for processes of using the heat generated and hot gases emitted during solid waste incineration include incinerator, boiler, steam and gas turbines and electric generators.

\subsection{Design of Incinerator}

The incinerator for the process shown in Figure 2, which is considered in this study, is the water-wall incinerator, which is useful for the recovery of steam and also in controlling furnace temperature without introducing excess air. A fluidised bed incinerator is considered for the process shown in Figure 2, and this burns solid waste at high pressure thereby producing hot gases that power a turbine and thus generate electricity.

\subsubsection{Combustion of Waste Materials}

Incineration conditions generally require excess oxygen to be present to ensure the formation only of products of complete combustion. Products of incomplete combustion result from insufficient oxygen. Incineration of sludge and solids require as much as two to three times excess air above stoichiometric equivalents but an extreme excess air should be avoided since it involves increased fuel for heat requirements, reduced residence time for the waste, and increased volumes of air emissions.

The principal elements of solid wastes are carbon, hydrogen, oxygen, nitrogen and sulphur. To compute the oxygen requirements for the oxidation of carbon, hydrogen and sulphur contained in solid waste, the following basic reactions are considered:

$$
\begin{gathered}
\mathrm{C}+\mathrm{O}_{2} \rightarrow \mathrm{CO}_{2} \\
2 \mathrm{H}_{2}+\mathrm{O}_{2} \rightarrow 2 \mathrm{H}_{2} \mathrm{O} \\
\mathrm{S}+\mathrm{O}_{2} \rightarrow \mathrm{SO}_{2}
\end{gathered}
$$

It is assumed that air contains $23 \%$ oxygen by mass. The amount of air required for the complete oxidation of $1 \mathrm{~kg}$ of carbon is $\frac{32 \times 1}{12 \times 0.23}=11.60 \mathrm{~kg}$.

The corresponding amounts of hydrogen and sulphur are $\frac{32 \times 1}{4 \times 0.23}=34.78 \mathrm{~kg}$ and $\frac{32 \times 1}{32 \times 0.23}=4.35 \mathrm{~kg}$ respectively.

All incineration processes operate in conformity with the first and second laws of thermodynamics.

The net heating value (NHV) of the waste mixture is determined assuming complete heat release of the incoming heating value. Usually, $60^{\circ} \mathrm{F}$ (i.e. $15.6^{\circ} \mathrm{C}$ ) is used as a reference temperature because heating value for the 
solid waste components are readily available and can be used in the relationship:

$$
\text { NHV of mixture }=\sum_{i=1}^{\infty} x_{i} \mathrm{NHV}_{i}
$$

In order to approximate the incineration temperature, assumptions to be made are:

1) The stoichiometric air requirement for any hydrocarbon waste is $0.01 \mathrm{ft}^{2} \cdot$ air/Btu. Using air at $60^{\circ} \mathrm{F}$, this requirement becomes $7.5 \times 10^{-4} \mathrm{Ib} \cdot \mathrm{air} / \mathrm{Btu}=3.22 \times 10^{-4}$ $\mathrm{kg} \cdot \mathrm{air} / \mathrm{kJ}$.

2) The heat capacity of the excess air (EA) is $0.3 \mathrm{Btu} /$ $\left(\mathrm{Ib} \cdot{ }^{\circ} \mathrm{F}\right)=0.7 \mathrm{~kJ} /\left(\mathrm{kg} \cdot{ }^{\circ} \mathrm{F}\right)$.

3) Adiabatic conditions exist in the incinerator.

The NHV for the waste mixture becomes:

$$
\begin{aligned}
\mathrm{NHV}= & \left(1+7.5 \times 10^{-4} \mathrm{NHV}\right)(0.3)(T-60) \\
& +(E A)\left(7.5 \times 10^{-4}\right)(\mathrm{NHV})(0.3)(T-60) \\
T=60 & +\frac{\mathrm{NHV}}{0.3\left[1+(1+E A)\left(7.5 \times 10^{-4}\right)(\mathrm{NHV})\right]}
\end{aligned}
$$

\subsubsection{Determination of Combustion Heat Balance}

To determine the heat available in the exhaust gases from the combustion of 4.5 tonnes/day of solid waste (Lagos State Waste Management Authority, LAWMA, Nigeria), the following components and compositions of solid waste are used (Clive, 2002), with basis of 100 tons/day of solid waste, as shown in Table 1.

It is assumed that the component has 5\% inert. From Table 1, the moisture content of municipal solid waste = $95-74.1=20.9$ tons, which was converted to hydrogen and oxygen tonnages thus:

Mass of hydrogen $=2 / 18 \times 20.9=2.32$ tons

Mass of oxygen $=16 / 18 \times 20.9=18.58$ tons

Total mass of oxygen $=30+18.58=48.58$ tons

Total mass of hydrogen $=4.58+2.32=6.90$ tons

Hence, the revised composition of the solid waste is presented in Table 2.
The calorific value of the waste is calculated from Equation (4) using the assumed composition in Table 1 as $13493.72 \mathrm{~kJ} / \mathrm{kg}$.

The energy content of the waste on a dry basis using Equation (2) is estimated to be $17059.06 \mathrm{~kJ} / \mathrm{kg}$.

The energy content of the waste on an ash-free basis using Equation (3) is estimated to be $18136.72 \mathrm{~kJ} / \mathrm{kg}$.

Other assumptions adapted from the literature [4] include:

1) The heating value of carbon $=32789 \mathrm{~kJ} / \mathrm{kg}$.

2) Heat lost through the reactor walls and other appurtenances to the surroundings $=0.004 \mathrm{~J} / \mathrm{kg}$ of furnace input.

3) Latent heat of vaporisation of water, $l_{v}=2420$ $\mathrm{kJ} / \mathrm{kg}$.

4) Specific heat of residue $=1.047 \mathrm{~J} / \mathrm{kg} \cdot \mathrm{K}$.

5) Unburned carbon in residue $=8 \%$ of input carbon.

6) Temperature of entering air (base temperature) = $25^{\circ} \mathrm{C}$.

7) Temperature of residue from the grate $=750^{\circ} \mathrm{C}$.

Heat losses from reactor (i.e. unburned carbon, radiation), from latent heat (i.e. inherent moisture, moisture in bound water, moisture from oxidation of net hydrogen) and from sensible heat (i.e. sensible heat in residue, stack gases) are all considered in this study.

Inert $=5 \%=5000 \mathrm{~kg} /$ day. Since the incinerator residue is assumed to contain $8 \%$ carbon, total residue $=$ $5 / 0.92=5.4348$ tons/day. Hence, carbon in residue $=$ $5.4348-5.0=0.4348$ tons/day.

The net value of hydrogen is computed by subtracting one-eighth of the percent oxygen from the total percentage of hydrogen present initially.

The net available hydrogen

$$
=\left(0.0726-\frac{0.5113}{8}\right) \times 100=0.87 \%
$$

Hydrogen in bound water $=7.26 \%-0.87 \%=6.39 \%$.

Bound water $=51.13 \%+6.39 \%=57.52 \%$.

Amount of water produced from combustion of hydrogen

\begin{tabular}{|c|c|c|c|c|c|c|c|c|}
\hline \multirow{2}{*}{ Component } & \multirow{2}{*}{ Wet mass/tons } & \multirow{2}{*}{ Dry mass/tons } & \multicolumn{6}{|c|}{ Composition } \\
\hline & & & $\mathrm{C}$ & $\mathrm{H}$ & $\mathrm{O}$ & $\mathrm{N}$ & $\mathrm{S}$ & Ash \\
\hline Food waste & 15 & 4.5 & 2.16 & 0.29 & 1.69 & 0.12 & 0.02 & 0.23 \\
\hline Cardboard & 10 & 9.5 & 4.18 & 0.56 & 4.24 & 0.03 & 0.02 & 0.48 \\
\hline Plastics & 10 & 9.8 & 5.88 & 0.71 & 2.23 & - & - & 0.98 \\
\hline Garden trimming & 10 & 4.0 & 1.91 & 0.24 & 1.52 & 0.14 & 0.01 & 0.18 \\
\hline Wood & 5 & 4.0 & 1.98 & 0.4 & 1.71 & 0.81 & - & 0.06 \\
\hline Total & 95 & 74.10 & 34.51 & 4.58 & 30.00 & 0.43 & 0.13 & 4.47 \\
\hline
\end{tabular}
$=\frac{18 \mathrm{~kg} \text { water }}{2 \mathrm{~kg} \text { hydrogen }}\left(\frac{0.0087}{1}\right)\left(\frac{100 \mathrm{tons}}{\text { day }}\right)-7.83$ tons/day

Hence, the heat balance for the combustion process is calculated thus:

Table 1. Compositions of solid waste. 
Table 2. Revised summary of solid waste compositions.

\begin{tabular}{ccc}
\hline Element & Mass/tons & \% by mass \\
\hline Carbon & 34.51 & 36.32 \\
Hydrogen & 6.90 & 7.26 \\
Oxygen & 48.58 & 51.13 \\
Nitrogen & 0.43 & 0.45 \\
Sulphur & 0.13 & 0.14 \\
Ash & 4.47 & 4.70 \\
Total & 95.02 & 100 \\
\hline
\end{tabular}

Gross heat input

$$
=\frac{100 \times 10^{3} \mathrm{~kg}}{\text { day }}\left(\frac{13493.72 \mathrm{~kJ}}{\mathrm{~kg}}\right)=1.3494 \times 10^{9} \mathrm{~kJ} / \text { day } .
$$

Heat lost in unburned carbon

$$
=\frac{0.4348 \times 10^{3} \mathrm{~kg}}{\text { day }}\left(\frac{32789 \mathrm{~kJ}}{\mathrm{~kg}}\right)=1.4261 \times 10^{7} \mathrm{~kJ} / \text { day } .
$$

Heat content of the inherent moisture $=m l_{v}=20.9 \times$ $10^{3} \times 2420=5.0578 \times 10^{7} \mathrm{~kJ} /$ day.

Moisture in bound water $=57.52 \times 10^{3} \times 2420=$ $1.3920 \times 10^{8} \mathrm{~kJ} /$ day.

Moisture from the oxidation of hydrogen $=7.83 \times 10^{3}$ $\times 2420=1.8947 \times 10^{7} \mathrm{~kJ} /$ day.

Radiation loss $=0.004 \times 100 \times 10^{3}=0.018 \mathrm{~kJ} /$ day.

Sensible heat in residue $=m c \theta==5.4348 \times 10^{3} \times$ $1.047 \times(750-25)=4.1254 \times 10^{6} \mathrm{~kJ} /$ day .

Sensible heat in hot gases $=(134.94-1.4261-5.0578$ $-13.920-1.8947-0.00004-0.41254) \times 10^{7}=112.25$ $\times 10^{7} \mathrm{~kJ} /$ day.

Hence, the heat released during incineration of 100 tons/day of solid waste was found to be $1.1225 \times 10^{9}$ $\mathrm{kJ} /$ day. As stated earlier, the amount of solid waste used in this work is 4.5 tons/day taken from LAWMA, Nigeria, hence, the sensible heat in hot gases $=5.0513 \times 10^{7}$ $\mathrm{kJ} / \mathrm{day}$, and this is the amount of heat used to produce steam in the boiler.

The design parameters of the incinerator are:

1) Capacity in terms of grate area and furnace volume.

2) Furnace diameter.

According to American Public Work Association in 1999, the required grate area in a conservative incinerator design is normally determined by limiting the burning rate between 290 and $340 \mathrm{~kg} /\left(\mathrm{m}^{2} \cdot \mathrm{h}\right)$ of grate area.

Using the maximum burning rate, grate area

$=\frac{\text { mass of waste }}{\text { burning rate }}=\frac{4500 \mathrm{~kg}}{\text { day }}\left(\frac{\mathrm{m}^{2} \cdot \mathrm{h}}{340 \mathrm{~kg}}\right)\left(\frac{1 \text { day }}{24 \mathrm{~h}}\right)=0.55 \mathrm{~m}^{2}$

The required furnace volume is established by the rate of heat release from the fuel, which ranges between $4.5 \times$ $10^{5}$ and $7.4 \times 10^{7} \mathrm{~kJ} /\left(\mathrm{m}^{3} \cdot \mathrm{h}\right)$, according to the American Public Work Association in 1999. Using the maximum rate of heat release, and assuming $18 \mathrm{~h}$ operation on three shifts with a down-time of $6 \mathrm{~h}$ daily, the waste capacity

$$
=\frac{4500 \mathrm{~kg}}{\text { day }}\left(\frac{1 \text { day }}{18 \mathrm{~h}}\right)=250 \mathrm{~kg} / \mathrm{h} \text {. }
$$

Heat content of solid waste

$$
=\frac{5.0513 \times 10^{7} \mathrm{~kJ}}{\text { day }}\left(\frac{\text { day }}{4500 \mathrm{~kg}}\right)=11225.11 \mathrm{~kJ} / \mathrm{kg} \text {. }
$$

Heat in waste $=$ waste capacity $\mathrm{x}$ heat content of waste

$$
=\frac{250 \mathrm{~kg}}{\mathrm{~h}}\left(\frac{11225.11 \mathrm{~kJ}}{\mathrm{~kg}}\right)=2.0863 \times 10^{6} \mathrm{~kJ} / \mathrm{h} \text {. }
$$

Volume of furnace

$$
\begin{aligned}
& =\frac{\text { total heat }}{\text { heat release rate }}=\frac{2.8063 \times 10^{6} \mathrm{~kJ}}{\mathrm{~h}}\left(\frac{\mathrm{m}^{3} \cdot \mathrm{h}}{7.4 \times 10^{5} \mathrm{~kJ}}\right) \\
& =3.80 \mathrm{~m}^{3} .
\end{aligned}
$$

The loading rate for fluidised bed incinerator ranges between 245 and $290 \mathrm{~kg} /\left(\mathrm{m}^{2} \cdot \mathrm{h}\right)$ [5]. Using the maximum loading rate, area of bed

$$
=\frac{\text { capacity }}{\text { loading rate }}=\frac{250 \mathrm{~kg}}{\mathrm{~h}}\left(\frac{\mathrm{m}^{2} \cdot \mathrm{h}}{290 \mathrm{~kg}}\right)=0.86 \times 10^{6} \mathrm{~m}^{2} .
$$

But area $=\pi D^{2} / 4$, hence the diameter of bed is obtained as $1.05 \mathrm{~m}$.

Height of bed,

$$
\mathrm{H}=\frac{\text { volume of waste }}{\text { area of bed }} \text {. }
$$

The approximate value of bulk density of solid waste $=$ $210 \mathrm{~kg} / \mathrm{m}^{3}$, according to the American Public Work Association in 1999.

Volume of waste/day

$$
=\frac{4500 \text { tons }}{\text { day }}\left(\frac{1}{210 \mathrm{~kg} / \mathrm{m}^{3}}\right)=21.43 \mathrm{~m}^{3} \text {. }
$$

Therefore, height of bed,

$$
\mathrm{H}=\frac{21.43 \mathrm{~m}^{3}}{0.86 \mathrm{~m}^{2}}=24.92 \mathrm{~m} \text {. }
$$

\subsection{Design of Boiler}

Assume a boiler efficiency of $75 \%$ [6].

Steam energy available $=5.0513 \times 10^{7} \times 0.75=3.7885 \times$ $10^{7} \mathrm{~kJ} /$ day.

The volume of water required in the boiler to be converted to steam using $5.0513 \times 10^{7} \mathrm{~kJ} /$ day of heat is determined as follows.

The operating temperature of most boilers ranges between $800^{\circ} \mathrm{C}$ and $930^{\circ} \mathrm{C} \mathrm{[7].} \mathrm{Hence} \mathrm{a} \mathrm{temperature} \mathrm{differ-}$ ence of $900^{\circ} \mathrm{C}$ is employed.

Heat required to produce steam in the boiler $=m c \theta$.

Mass of water,

$$
m=\frac{5.0513 \times 10^{7}}{4.2(900+273)}=10253.12 \mathrm{~kg} / \mathrm{day}
$$

Volume of water required 


$$
=\frac{\text { mass }}{\text { density }}=\frac{10253.12}{1000}=10.25 \mathrm{~m}^{3} / \text { day } .
$$

\subsection{Design of Combustion Gas Turbine}

Assume the efficiency of the gas turbine is $40 \%, p_{A}=1$ at $m$ and $\gamma=1.4$.

Using Equation (17), $p_{B}$ was found to be 6 at $\mathrm{m}$ hence, the compression ratio of the turbine is 6 .

Using Equation (19), $\alpha=1.4$.

Assuming the maximum and minimum permissible temperatures in the turbine are $750^{\circ} \mathrm{C}\left(1382^{\circ} \mathrm{F}\right)$ and $25^{\circ} \mathrm{C}$ $\left(77^{\circ} \mathrm{F}\right)$ respectively, then $\frac{T_{C}}{T_{A}}=\frac{1382+460}{77+460}=3.43$.

Assuming the centrifugal compressor and the gas turbine operate adiabatically and irreversibly with efficiencies of $\eta_{c}=0.8$ and $\eta_{t}=0.85$ respectively, using Equation (18), $\eta$ was found to be 0.209 . This shows that even with a rather efficient centrifugal compressor and gas turbine, the ideal efficiency is drastically reduced from assumed value of $40 \%$ to approximately $21 \%$.

\subsection{Design of Electric Power Generator}

The auxiliary power allowance is assumed to be $6 \%$ of the power produced [8].

Process heat losses are assumed to be 5\% [8].

Computations of energy output and efficiency for steam boiler-turbine-generator energy-recovery plant from the incineration of 4.5 tons/day solid wastes with an energy content of $13493.72 \mathrm{~kJ} / \mathrm{kg}$ are given below.

Energy available in solid waste

$$
=\frac{4.5(1000)(13492.72)}{24}=2.53 \times 10^{6} \mathrm{~kJ} / \mathrm{h} .
$$

Steam energy available $=2.53 \times 10^{6} \times 0.75=1.90 \times$ $10^{6} \mathrm{~kJ} / \mathrm{h}$.

From Tchobanoglous et al. [9], heat rate

$$
=\frac{3600 \mathrm{~kJ} / \mathrm{kW}-\mathrm{h}}{0.316}=11392.41 \mathrm{~kJ} / \mathrm{kW}-\mathrm{h}
$$

Electric power generation

$$
\begin{aligned}
& =\frac{\text { steam energy available }}{\text { heat rate }}=\frac{1.90 \times 10^{6} \mathrm{~kJ} / \mathrm{h}}{11392.41 \mathrm{~kJ} / \mathrm{kW}-\mathrm{h}} . \\
& =166.78 \mathrm{~kW}
\end{aligned}
$$

Station service allowance $=166.78 \times 0.06=10.01 \mathrm{~kW}$.

Unaccounted heat losses $=166.78 \times 0.05=8.34 \mathrm{~kW}$.

Net electric power for a community $=166.78-10.01$ $-8.34=148.43 \mathrm{~kW}$.

Overall efficiency

$$
=\frac{148.43(3600)}{2.53 \times 10^{6}} \times 100=21.12 \% .
$$

Assuming 10\% of the power generated is used for the front-end processing system, then the net power for a community is $133.59 \mathrm{~kW}$, and the overall efficiency is $19 \%$.

\subsection{Exergy Analysis of CHP Plant}

Exergy is the portion of the total energy embedded in a system that is available for conversion to useful work. The exergy of a system can be increased if exergy is input to it [10]. Exergy analysis yields efficiencies, which provide a measure of how nearly actual performance approaches the ideal, and identifies more clearly the causes and locations of thermodynamic losses than does the energy analysis. Consequently, exergy analysis can assist in improving and optimising design [11].

Exergy analysis of CHP plant explains how efficient the equipment units are, how useful part of the energy will be known and quantified to increase the overall efficiency of the whole CHP plant. For the exergy analysis and evaluation of energy and exergy efficiencies, the following assumptions are made:

1) The reference environment temperature, $T_{o}$, is $25^{\circ} \mathrm{C}$.

2) The thermal product is delivered at an effective temperature, $T$, of $900^{\circ} \mathrm{C}$.

3) The energy and exergy of combustible waste are identical.

The flow of exergy associated with the heat transfer, $Q$ is given by [10]:

$$
E_{X Q}=\int_{Q_{i}}^{Q_{f}}\left(1-\frac{T_{o}}{T}\right) \delta Q
$$

which is the minimum work required by the combined system of the control mass and environment in bringing the control mass from an initial state to final state, $\delta Q$ is an incremental heat transfer. If the temperature, $T$, of the control mass is constant, the thermal exergy transfer associated with a heat transfer is:

$$
E_{X Q}=\left(1-\frac{T_{o}}{T}\right) Q=\tau Q
$$

with $\tau=1-\frac{T_{o}}{T}=1-\frac{298}{1173}=0.7460$.

Therefore, thermal exergy transfer

$$
=0.7460\left(5.0513 \times 10^{7}\right)=3.7683 \times 10^{7} \mathrm{~kJ} / \text { day } \text {. }
$$

This is the exergy associated with energy of $5.0513 \times$ $10^{7} \mathrm{~kJ} /$ day, which is also a quantitative assessment of its usefulness or quality.

The energy and exergy efficiencies are calculated as follows:

Energy efficiency,

$$
\begin{aligned}
\eta & =\frac{\text { energy output in product }}{\text { energy input }} \\
& =\frac{5.0513 \times 10^{7}}{1.3494 \times 10^{9}(4.5 / 100)} \times 100 \%=83.2 \%
\end{aligned}
$$

Exergy efficiency, $\psi$, is found thus: 


$$
\begin{aligned}
\psi & =\frac{\text { energy output in product }}{\text { exergy input }} \\
& =1-\frac{\text { exergy loss }}{\text { exergy input }} \\
& =\frac{3.7683 \times 10^{7}}{1.3494 \times 10^{9}(4.5 / 100)} \times 100 \%=62.1 \%
\end{aligned}
$$

The exergy efficiency is thus lower than energy efficiency. This provides a true measure of how nearly actual performance approaches the ideal. It also identifies more thermodynamic losses, which can be taken care of in optimising design.

For boiler, an efficiency of $75 \%$ is assumed so exergy efficiency $=\frac{3.7683 \times 10^{7}}{1.3494 \times 10^{9}(4.5 / 100)} \times 100 \%=46.6 \%$.

This means that for boiler operating at $75 \%$ efficiency, the useful energy that can be obtained from it is approximately $47 \%$ of the energy in the boiler.

\section{Conclusion}

This study shows that the Combined Heat and Power (CHP) plant is a feasible project that can be embarked upon in Nigeria since its major raw materials (solid wastes) are readily available. In the face of epileptic power supply, CHP plant can be developed for generation of electricity to a small community (such as housing complex, institutions of higher learning but to mention a few), using an incinerator-boiler-steam turbine-electric generator or incinerator-gas compressor-gas turbinegenerator, and this will reduce dependence of communities on the national grid for electricity consumption. Having taken cognisance of allowances and heat losses, the net power for a community was found to be 148.24 $\mathrm{kW}$ based on the composition of 4.5 tons/day of solid waste used in this work. The low power value is due to low tonnage of solid waste used coupled with the exclusion of detailed design of each item of equipment as the choice, design and sizing of CHP plant is crucial. Moreover, exergy analysis of the CHP plant was carried out, and the energy and exergy efficiencies were $83.2 \%$ and $62.1 \%$ respectively. This low efficiency value of exergy provides a true measure of energy quality thus it indicates the amount of energy being used up in the system. Consequently, more thermodynamic losses are identified which can be incorporated in optimising the design of CHP plant.

\section{REFERENCES}

[1] O. Iyiola, "Effective Solid Waste Management: Integrated, Decentralised, Cost-Effective and Market-Based Approach," The Workshop on Effective Solid Waste Management, Lagos, August 2009.

[2] O. A. Olafadehan, "The Design of a Solid-Waste Management System with Material and Energy Recovery," Master's Thesis, University of Lagos, Lagos, 1994.

[3] Y. Okunubi, "Fundamentals of Solid Waste Management Policies and Practices," The Workshop on Effective Solid Waste Management, Lagos, August 2009.

[4] T. Howard and B. Odum, "Concept and Methods of Ecological Engineering," Environmental Engineering Sciences, University of Florida, Gainesville, 2008.

[5] L. Theodore and J. Reynolds, "Introduction to Hazardous Waste Incineration," Wiley, New York, 1987.

[6] L. V. Ralph, "Practical Guide to Industrial Boiler System," McGraw-Hill Inc., New York, 2001.

[7] M. S. Peter, K. D. Timmerhaus and R. E. West, "Plant Design and Economics for Chemical Engineers," McGrawHill Chemical Engineering Series, New York, 2003.

[8] B. Clive, "Energy Management, Supply and Conservation," British Library Cataloguing in Publication Data, London, 2002.

[9] G. Tchobanoglous, H. Theisen and Eliassen, R. "Engineering Principles and Management Issues," McGraw-Hill, New York, 1972.

[10] I. Dincer and M. Rosen, "Exergy, Environment and Sustainable Development," Khiwer, Academic, 2007.

[11] B. K. Adeoye, "Achieving Sustainable Development in Combined Heat and Power System-An Exergy Analysis," Master's Thesis, University of Lagos, Lagos, 2010. 


\section{Notation}

$A^{\prime} \quad$ percentage of ash in the solid waste

$a \quad$ initial mass of solid-waste sample as delivered, $\mathrm{kg}$

$b \quad$ mass of sample after drying, $\mathrm{kg}$

$C$ percentage of carbon in the solid waste

$C_{p} \quad$ specific heat at constant pressure, $\mathrm{J} /(\mathrm{kg} \mathrm{K})$

$E^{\prime} \quad$ energy content of solid waste on an ash-free basis, $\mathrm{kJ} / \mathrm{kg}$

$E \quad$ energy content of solid waste on a dry basis, $\mathrm{kJ} / \mathrm{kg}$

$E_{d} \quad$ energy content of solid waste as discarded, $\mathrm{kJ} / \mathrm{kg}$

$g$ acceleration due to gravity, $\mathrm{m} / \mathrm{s}^{2}$

$H$ percentage of hydrogen in the solid waste

$\Delta H \quad$ enthalpy change, $\mathrm{J} / \mathrm{mol}$

$M \quad$ percentage of moisture in the solid waste
$O$ percentage of oxygen in the solid waste

$p \quad$ pressure, $\mathrm{N} / \mathrm{m}^{2}$

T temperature, ${ }^{\circ} \mathrm{C},{ }^{\circ} \mathrm{F},{ }^{\circ} \mathrm{R}$

$U$ velocity of fluid stream, $\mathrm{m} / \mathrm{s}$

$W_{s} \quad$ actual work of a process (shaft work), $\mathrm{J}$

$\Delta z \quad$ change in elevation, $m$

\section{Greek symbols}

$\eta \quad$ efficiency of a machine

$\eta_{c} \quad$ efficiency of the compressor

$\eta_{t} \quad$ efficiency of the turbine

$\tau \quad$ energetic temperature factor, dimensionless

\section{Subscripts}

c compressor

$f \quad$ final state

$i \quad$ initial state

$t$ turbine 